\title{
The Balanced Obligation and the Basis for Compliance in International Law: Reflections on the Question of International Obligation
}

\author{
Thomas Prehi Botchway ${ }^{1}$ \\ ${ }^{1}$ Law School, Chongqing University, Shapingba, Chongqing, China \\ Correspondence: Thomas Prehi Botchway, Law School, Chongqing University, Shapingba, Chongqing, China. \\ E-mail: abeikuprehi@yahoo.com; prehionline@gmail.com
}

Received: March 7, 2019

Accepted: March 22, 2019

Online Published: May 30, 2019

doi:10.5539/jpl.v12n2p23

URL: https://doi.org/10.5539/jpl.v12n2p23

\begin{abstract}
In this essay, we use the implementation of multilateral environmental agreements (MEAs) in developing countries (specifically, the implementation of the Convention on Biological Diversity in Ghana) to illustrate why and how States can implement international agreements and for that matter comply with international law without necessarily compromising on equally implementing effective policies to meet their domestic responsibility, particularly when such MEAs may be deemed by some as instruments that curtail the enjoyment of benefits from a State's natural resources and endowments.

The essay examines the nexus between compliance with international law (international obligation) and meeting domestic responsibility (particularly when the international treaty or agreement to be complied with seems to have some negative implications for the domestic population or State policy). Do States always have an incentive to comply with and execute their international obligations? Should the need for or argument against an international agreement or treaty necessarily lead to its abandonment by States? Can States effectively balance the execution of international obligation with meeting domestic responsibility? Should the effective implementation of a State's international obligation be regarded as a zero sum for the State's domestic responsibility? What should be the basis for compliance in international law? These are some of the few questions that this essay seeks to address.
\end{abstract}

Keywords: international law, international obligation, domestic responsibility, balanced obligation, compliance

\section{Introduction (Note 1)}

Evidence exists in our world to show that in the current International System States usually implement treaties or conventions and customary international law in accordance with their own understanding of what international law is and not necessarily what it ought to be. Even when the wordings of treaties are very clear, precise and categorical, some States have attempted to reinterpret the texts of legally agreed documents. (Chayes \& Chayes, 1986) Moreover, despite divergent views on the nature of international law and its relations with domestic or municipal law, studies have shown that there are two main approaches to international law and that each approach takes into consideration how international law relates to national law. These are namely the monist theory which asserts that "there is one all-embracing legal order comprising international and national law", and the dualists view which stipulates that there are "two separate legal systems; international and national." (UNESCO, 2011, p. 64) Eventually, while proponents of the monist approach assert that incorporation is the basis for the application of international law at the municipal level, dualists claim that since the two are different sets of law, there is the need for a 'transformation' of the former by way of a statute or an Act of Parliament for it to be applicable in the latter. (D'Amato, 2009; Hamid \& Sein, 2005)

Though these theories of international law would have served as an ideal starting point for explaining the implementation of multilateral environmental agreements (MEAs) in developing countries, the essay takes the position that theorizing about the types of law would not necessarily lead to a better explanation of why the State does what it does. Of course, the monists and dualist theories of law would only be able to explain why a certain convention, treaty, or agreement will be ratified, and the processes involved in such ratification, but will be insufficient in explaining what happens after ratification. It is here that the essence and questions about the 
theories of international obligation come in. It is the theory of international obligation (in its various forms) that best explains the rationale or justification for a State's (and in this case developing countries') implementation or otherwise of an international treaty such as the Convention on Biological Diversity (CBD), the Paris Climate Accord, the United Nations Framework Convention on Climate Change (UNFCCC), the Ramsar Convention, etc.

We shall turn to the details of the theory soon, but for now, it is important to note that the application of international laws, conventions and treaties usually vary from country to country. For instance, whereas in New Zealand treaties are viewed as part of a separate legal system that must be adopted and implemented by domestic laws in order for it to have any legal effect, in Mongolia when a domestic law is found to be inconsistent with an international treaty, the latter takes preeminence. This stems from the idea that international treaties create contractual obligations that have been agreed to by the parties and are as such legally binding on those who are party to it. Thus, the nature of international law demands that once a State becomes party to a treaty, it has an obligation to observe and implement it in good faith, and that States cannot excuse non-compliance with a treaty just because it is incompatible with national laws. (This still remains a controversial issue in International Law and its related subjects - there are diverse views even as there are diverse States in the international system). This notwithstanding, with regards to customary international law, it may not be binding on a State as long as the State in question has explicitly objected to the custom during its formation period - the idea of the persistent objector. (UNESCO, 2011)

Moreover, whereas some treaties are 'self-executing', others are not. That is to say some treaties require national legislation to bring them into effect at the national level but others do not. By their very nature, most MEAs require ratification; and particularly for common law countries like the United Kingdom, Ghana, Australia, New Zealand, etc. whose Constitutions usually demand so in virtually all cases. Issues of implementation of international treaties usually brings to the fore the question of sovereignty of States and national/domestic interests in the international system, and this partly informs questions of international obligation and domestic responsibility.

Though sovereign States may occasionally opt for a unilateral modification of their international obligations by entering a reservation at the initial stages of the negotiation for a treaty or convention, this practice is usually frowned upon by other parties and may lead to unwarranted suspicions on their part. This reason is partly responsible for a particular State's participation in a treaty yet unwillingness to execute the tenets of the agreement. Moreover, States are also entitled to "make declarations, which set out their intentions with respect to applying the provisions of a treaty, as well as make interpretations which can have legal effect or may simply be interpretative." (UNESCO, 2011, p. 64) In the absence any reservation or declaration, the provisions of any agreed treaty are usually legally binding on all parties (He, 2016; Pemmaraju, 2016).

A key feature of most MEAs is the provision of a general framework around which parties are expected to operate. This seemingly flexible nature of MEAs allows States the opportunity of adapting their international obligations to correspond with their particular socio-economic and political dynamics. It is however usually the hope of the international community that every State "earnestly implement their obligations into law" since this will be beneficial for the overall protection of the environment and global conservation of biodiversity and their sustainable use. The problem however is that this flexibility is usually taken advantage of either willfully or due to some genuine yet solvable problems. The point is that "it may be politically convenient for States to take advantage of the flexibility by half-heartedly implementing their obligations and at the same time being able to say they have discharged their obligations to the best of their ability." (UNESCO, 2011, p. 64)

\section{The Theory of International Obligation: A Variegated Dimension}

Theories of international obligation usually begin from the premise that in their daily interaction and international cooperation, States in the international system owe obligations to the international community as a whole, and that such obligations are intended for the protection and promotion of the essential values and general interests of all in the community of States. The theory then implies that it is a must for States to undertake and also refrain from certain actions, particularly those that have been categorically codified in treaties, conventions, agreements, declarations, etc. or exist over the years and have been recognised as customary practices. A breach of such internationally accepted practices usually comes with consequences in diverse forms. (D'Amato, 2010; Dominicé, 1999)

The theory of international obligation has several variations and versions which are aimed at explaining why States are obliged to do some things and to refrain from doing others. There are those who argue that international obligation is rooted in morality; that is to say there is moral obligation. There are equally those who 
are opposed to this idea of moral obligation. There are also arguments for reputational effects, as well as those for coincidence of interests, and the transnational legal process. Even some have used Garrett Hardin's "Tragedy of the Commons" to explain why States obey international laws. (Ferrey, 2003; Hardin, 1968) To others, laws being it a municipal or international law, "must be enforced by physical sanctions" to ensure compliance. (D'Amato, 2009, p. 440) However, for purposes of brevity and clarity, I shall use the analyses of a few renowned modern scholars to illustrate some variations of the theory. These include the works of Eric Posner, Andrew T. Guzman, Harold Hongju Koh, Christian Reus-Smit, etc.

In trying to answer the question as to whether Israel should "have refrained from kidnapping" Adolf Eichmann from Argentine territory in 1960 since the act violated international law, Eric Posner has argued that the answer to the question lies in two folds. According to him, the first answer "assumes that the only reason to comply with international law is to avoid retaliation from other nations or to avoid their distrust." Posner argues that "the second possible answer to the question is that Israel should have refrained from kidnapping Eichmann because it is wrong to violate international law" and that "the wrongfulness of violating the law is distinct from the wrongfulness, if any, of kidnapping Eichmann.” (Posner, 2003, p. 1901)

Posner has indicated that adopting the position of the first answer implies that "international law is a source of expectations about how states will act under various conditions" and that "if an international law forbids behavior X, then states might retaliate against someone who engages in X" though a State's decision to retaliate or not largely "depends on their own interests and capacities." Consequently, States usually make "cost-benefit decision" to ascertain the likely "reputational consequences of that decision." In other words, for a State to retaliate against a non-complying State or for the State to be non-compliant all hinges on the reputational interest and consequences of the action on the State in question. However, Posner has opined that as far as the second view is concerned "international law is a source of moral obligations that influence states by constraining their prudential decisions" and that "states do not have a general moral obligation to comply with international law." (Posner, 2003, p. 1902)

Posner has argued elsewhere that "there is no international law requiring states to keep their promises." (Posner, 2003, p. 1905) He makes a distinction between a promise and a treaty and argues that no State is under any moral obligation to keep the former. The implication therefore is that States are free to violate international promises and are not under any 'moral' obligation to obey international law if such a law could go against their domestic interests. Posner (2003) has also taken the position that State consent which usually emanates from the principle of pacta sunt servanda (Note 2) "is not a sufficient condition for creating an obligation...." According to him, "[a] promise, which is an act of consent, is not a legal obligation" and that "[w]hat is necessary for an act of consent to create a legal obligation is the satisfaction of additional formalities which themselves are not the creation of the parties." (Posner, 2003, p. 1909)

For Posner, the most reasonable explanation for a State's compliance with international law is because "the law is so exceedingly weak" and "the rules are vague" and States can always "withdraw from treaties, and so forth-and when the law is not weak, states frequently violate it." (Posner, 2003, p. 1914) There is therefore no such thing as a moral obligation to international law. In effect, States are believed to "have an intrinsic desire to comply with international law for reasons other than moral obligation." (Posner, 2003, p. 1918) Thus, there is the idea that States only comply with international law and agreements, particularly multilateral environmental agreements "because of shallow cooperation" and that most countries expend considerable "time and resources negotiating agreements reflecting no more than current domestic policies." (Crossen, 2003, p. 5)

Similarly, Christian Reus-Smit (2003) has indicated that observance of rules by States in the international system is because such international laws are "...frequently in the narrow self-interest of states" and "partly because non-observance can undermine a state's reputation and in turn its capacity to pursue its interests in other issue-areas, and partly because a growing number of legal regimes have formal sanctioning mechanisms." Moreover, it is argued that "most states recognize an obligation to observe the rules of international law" because "they consider it right to comply with those rules and norms deemed legal." (Reus-Smit, 2003, p. 592)

Using case studies from three traditional areas of customary international law, namely "neutrality, diplomatic immunity, and maritime jurisdiction", Posner and Goldsmith (1999, p. 1113) developed a theory of customary international law (CIL) that postulates that;

Most rules of CIL reflect pure coincidence of interest, rather than international cooperation, and that the rest are best explained as the outcome of repeated bilateral prisoner's dilemmas or coercion analogous to the behavior of the monopolist in predatory pricing games.

Their study therefore argues that the ideas of either a legal or moral obligation serving as tenets for State 
compliance with customary international law are untenable. On the contrary, it is said that a State's compliance and accompanying norms actually "emerge from the states' pursuit of self-interested policies on the international stage." (Posner \& Goldsmith, 1999, p. 1113)

The duo also insist that unlike CIL that "lacks a centralized lawmaker, a centralized executive enforcer, and a centralized, authoritative decisionmaker", conventions, treaties, bilateral investment treaties (BITs), memorandum of understandings (MOUs), multilateral agreements and other soft laws have relatively more defined institutionalized procedures for legislation, execution, and enforcement. Moreover, whereas the content of CIL usually appears to be a reflection of the interests of powerful States, treaties, conventions, MOUs and the so-called soft laws usually gives room for a seemingly equality and reflects the aspirations of all the parties involved. (Posner \& Goldsmith, 1999, p. 1114) This is not to say that these forms of international laws actually promote equality in the true sense of the word; they may not. Instead, they may give a relatively fair representation of interests as opposed to that of CIL that are usually claimed to be linked with the so-called laws and practices of civilized nations.

Whereas most legal scholars and international lawyers usually evaluate the outcomes of international environmental agreements (IEAs) by way of analyzing the extent to which parties to such IEAs act in accordance with their obligations as spelt out in such IEAs, their counterparts in the international relations field are inclined to examining the effects of IEAs through a wide-ranging array of inquiries and multiplicity of questions. (Mitchell, 2007) The bottom-line however is that the question of 'why' States obey international law is essential to understanding the theoretical as well as the practical applications and formulations of rules and regulations in the international system. This question challenges both scholars and practitioners of international relations and international law in their respective fields of operation. It consequently "vexes all subfields in international affairs, from international security to political economy; from international business transactions to international trade; from European Union law to international organizations." (Koh, 1997, p. 2600)

It is with the hope of addressing the intricacies of why States obey international law that some have proposed the managerial approach to understanding the issue. According to the managerial approach to compliance with international law (as proposed by Abram and Antonia Handler Chayes), States "obey international rules not because they are threatened with sanctions, but because they are persuaded to comply by the dynamic created by the treaty regimes to which they belong." (Cited in Koh, 1997, p. 2601) According to Koh however, three important processes namely "interaction, interpretation, and internalization of international norms into domestic legal systems" are fundamental to "understanding why nations 'obey' international law, rather than merely conform their behavior to it when convenient." (Koh, 1997, p. 2603; 1998, p. 626) Koh has also indicated that the "Austinian, positivistic realist" school of thought regarding the question of compliance with international law propose that States "never "obey" international law, because "it is not really law."' (Koh, 1997, p. 2611) Thus for the Austinians, the argument partly stems from the fact that there must be a determinate sovereign from whom the laws emanate and who also ought to ensure compliance with these rules and who must not be subjected to any law whatsoever.

In the past few decades, the establishment of presumably more coherent and well-structured institutions such as the United Nations, World Bank, International Monetary Fund (IMF), World Trade Organisation (WTO), etc. with their "intensely regulatory global framework" after the Second World War was anticipated to be a formidable foundation for the effective application of legal rules that would "reflect international systemic concerns, rather than parochial interests." (Koh, 1997, p. 2614) Though these institutions have been very useful in several respects, doubts still abound as to whether they have been able to effectively address the question of parochial interests (especially of the so-called major powers). (Botchway, 2018; Botchway \& Kwarteng, 2018; Kwarteng \& Botchway, 2018; International Commission on Intervention and State Sovereignty [ICISS], 2001)

Over the years, the New Haven School initiated at Yale by Myres McDougal, Harold Lasswell and their associates have constantly asserted that "international law is not a body of rules, but a process of authoritative decisionmaking" (Koh, 1997, p. 2620) Also very prominent is the International Legal Process School whose key proponents of include Abram Chayes, Antonia H. Chayes, Louis Henkin, Thomas Ehrlich, and Andreas Lowenfeld. Whereas the New Haven School on the one hand views international law as "a decisionmaking process dedicated to a set of normative values", the International Legal Process School on the other hand perceives the field and practice as a "set of rules promulgated by a pluralistic community of states, which creates the context that cabins a political decisionmaking process." (Koh, 1997, p. 2623)

Koh (1997) has described the Chayesian or Managerial approach to compliance in the international system as "Compliance Without Enforcement" since the "enforcement" model developed by the Chayeses which included 
a variety of "coercive devices available-treaty-based military and economic sanctions, membership, and unilateral sanctions" are usually destined to fail. (Koh, 1997, pp. 2635-36) He consequently concludes his essay by asserting that "participation in transnational legal process creates a normative and constitutive dynamic" and that through the interpretation of "global norms, and internalizing them into domestic law, that process leads to reconstruction of national interests, and eventually national identities." According to him, in this "post-ontological age, characterized by the "new sovereignty', the richness of transnational legal process can provide the key to unlocking the ancient puzzle of why nations obey." (Koh, 1997, p. 2659; 1998, p. 626)

For Christian Reus-Smit (2003), the "flawed conceptions of politics that underlie" many studies have over the years also led to a misconception about the obligation of States "to observe the rules of international law." It is in hope of addressing this problem that he puts forward "an alternative, "interstitial' understanding of politics that locates politics at the intersections of idiographic, purposive, ethical and instrumental forms of reason and action." Reus-Smit consequently posits that "this understanding of politics" will actually facilitate a rethinking of "the nature of institutional rationality, and in turn the bases of international legal obligation." (p. 591) There is therefore the trust that the "sense of obligation is a crucial factor in explaining both the attraction of international law as a regulatory institution" and that this sense of obligation goes a long way to ensure that States "avoid legal entanglements." That is to say, in the absence of incurring "obligations", international law will "have little attraction in a world where narrow self-interest and fear of sanctions are insufficient on their own to sustain extensive cooperation." (Reus-Smit, 2003, p. 592)

Reus-Smit (2003) has consequently indicated that a better understanding of "why states recognize an obligation to observe international legal rules" requires that we first "must adopt a broader conception of politics than the rationalist understanding commonly advanced by International Relations scholars." And secondly, there is the need to understand that "a satisfactory account of international legal obligation must ultimately be historical-sociological in nature." In other words, "the interstitial conception of politics is non-universalistic" and it is this that should encourage people to perceive "politics as historically and socially contingent" phenomenon. For instance, the political system in the People's Republic of China is not the same as that of Australia, United Kingdom, or Ghana, etc. Reus-Smit (2003) consequently asserts that such an understanding of politics will also mean that "the reasons why actors create institutions, the institutional forms they adopt, the legitimacy they attach to those institutions" as well as "the obligations they accept under such institutions will also be historically and socially grounded." (Reus-Smit, 2003, p. 594) For Reus-Smit however, the recognisation that a State "is obliged to act in a given way is to recognize that one is expected to act that way even when it conflicts with one's own interests" irrespective of the fact that distinction can be made "between political, moral and legal obligations." (Reus-Smit, 2003, p. 595)

Reus-Smit (2003) is not alone in his call for a proper understanding of Politics and International Law. In fact, elsewhere, over a decade prior to his assertion above, Anthony Carty has argued that in order to construct a formidable "legal translation", a fundamental step would be the "deconstruction" of the "universalist compulsion" and the "monist western theory of law" that traces their root in the Platonic conception of human unity and to the "Christian belief that every kingdom divided against itself must fall" - conceptions that actually hamper pluralism in the legal realm. (Carty, 1991, p. 2)

According to Teson (1990), disputes in the international system "very rarely take the form of one nation seeking to enforce its international legal rights against another nation asserting an entitlement to disobey international law on grounds, say, of self-interest." In his view, "the vast majority of international controversies" in the system stems from "what international law permits, prohibits or commands" and that "governments" will hardly "claim the right to disregard international law, even when they believe that their most basic national interests are at stake." (p.85) For Teson, "[t]here is no real dispute about the proposition that nations must honor international law; rather, disputes are about what international law requires." (Teson, 1990, p. 87) However, recent activities in the international system in modern history tends to somewhat disprove some of Teson's assertions - for instance the US' withdrawal from the Paris Climate Agreement, the Iran Nuclear Deal, the International Criminal Court, the boycotting of the Kyoto Protocol, the opening of the US Embassy in Jerusalem, the recognition of opposition groups as the 'legitimate representatives' or 'interim president' (as in the case of Venezuela most recently) and even the very refusal to ratify the Convention on Biological Diversity (CBD), etc. all attest to the shortcoming of some of Teson's assertion. This stems from the fact that in most of these cases, the US clearly defies international law (and even teaches others to do same).

Teson's (1990), argument on actual consent as the basis of international obligation can best be described as the conditionality of consent as he proposes that only legitimate and truly delegated governments acts can be regarded as "acts of the state" in the international system. He even argues that though "legitimate governments" 
may at times "have to negotiate with illegitimate governments", the "agreements reached under such conditions are binding if they further the human rights cause of the oppressed populations" but "there is no general moral obligation to honor agreements with unrepresentative governments." (Teson, 1990, p. 104) For him, "international legal obligations cannot be determined solely by reference to what states have consented to in the past" and that "what custom and treaty language mean has to be determined in accordance with principles that transcend consent itself." (Teson, 1990, p. 105)

Teson (1990) outlines a basis of international law anchored on the principles of a "social contract theory" which he believes forms a formidable foundation for what he calls the "rational hypothetical consent" (p.109). He claims that the adoption of the hypothetical consent he proposes enhances giving "allegiance to principles of international justice that would be agreed upon in a fair bargain, in an original position where constraints would be introduced so as to bring about an agreement which is fair to all." He also posits that "the move from actual to hypothetical consent is a shift from positivism to natural law theory in its social contract version" and that it is no longer tenable to argue that "the consent of states is the basis of obligation but rather that international law... must be seen and interpreted in light of the principles of international justice that would result from a hypothetical, original contract." (Teson, 1990, p. 109) In a similar vein, Anthony D'Amato has argued that “...if consent supervened upon enforceability - as the consent theory implied" then there would not be any "logical reason why a state could not simply withdraw its consent to any particular rule whenever it found the rule to impede its immediate interests." (D'Amato, 2010, p. 2)

Teson (1990) therefore concludes his essay by arguing that society "should never forget that all law, including international law, is made to solve the problems that confront us as autonomous moral agents" and that "every set of institutions should make room for that imprescriptible entitlement to human dignity" (p. 120). Though the essay disagrees with some of Teson's earlier assertions as indicated above, this particular view resounds quite well with the author's understanding of why most countries implement multilateral environmental agreements (or at least claim to be implementing them). The conclusion of the paper shall highlight the author's view on this matter - the need for all institutions and laws to focus on addressing "entitlement to human dignity."

Another scholar who attempts to explain why States obey international law is Andrew T. Guzman who in his seminal work "A Compliance-Based Theory of International Law" proposes a "theory of international law in which compliance comes about in a model of rational, self-interested states." According to Guzman, "international law can affect state behavior because states are concerned about the reputational and direct sanctions that follow its violation." (Guzman, 2002, p. 1825)

Guzman's (2002) "Compliance-Based Theory of International Law" while not rejecting the "liberal approach" to understanding international law as spearheaded by international relations scholars, mainly "draws upon the institutionalist tradition of international relations" in an attempt to build a theory that explains why States do comply international law. His theory which is cast in the frame of a mixture of "neorealism and institutionalism" consequently presupposes that in their interactions with the global system, States are basically "independent" and "act only in their own self-interest." A major shift from the institutionalist thought as depicted in Guzman's compliance theory is that customary international law and treaties are not the only subjects that have to be conceived as the fundamentals of international law. Guzman's theory of compliance eventually complements the liberal theory of international relations that attempts to explain the basis for international law. (p. 1840)

Guzman has at a point argued that since "the negotiation of international treaties and other agreements consumes resources that a state could use in other ways", it will be unreasonable for any State to "waste resources on international legal conventions and negotiations" if "international law does not have any impact" on State behavior. (Guzman, 2002, p. 1844) He also opines that "[a] good reputation is maintained as long as a country honors all of its previous international commitments" (Guzman, 2002, p. 1847) and that such a reputation "causes future relationships to be affected by today's actions." (Guzman, 2002, p. 1849) He subsequently asserts that the dearth of extra "enforcement mechanisms" to promote State obligation with international law would automatically mean that "a state's commitment is only as strong as its reputation" and that at the entrance into an international agreement, a State basically "offers its reputation for living up to its commitments as a form of collateral." (Guzman, 2002, p. 1849)

Guzman consequently identifies a number of issues that usually determines the "reputational impact of a violation" namely "(1) the severity of the violation, (2) the reasons for the violation, (3) the extent to which other states know of the violation, and (4) the clarity of the commitment and the violation." (Guzman, 2002, p. 1861)

Moreover, as regarding the issue of reputational effect been the basis of obligation and compliance with international law, the argument in most quarters have been that "[a] state can benefit from international 
cooperation only if other states believe that it will usually keep its promises" and that States in the international community "try to keep their promises in order to persuade other states that they are reliable." (Posner \& Goldsmith, 1999, p. 1136) More so, there is the idea that States do not usually violate treaties for the fear of retaliation but "not because they feel an obligation." (Posner \& Goldsmith, 1999, p. 1171)

Eventually, as can be seen from the works of several scholars (at least as can be seen from the preceding discussion), State compliance and obedience to international law (when they do) can be explained as resulting from "a complex combination" of five key factors namely "coercion, self-interest, rule-legitimacy, communitarianism, and internalization of rules through socialization, political action, and legal process." (Koh, 1998, pp. 633-634) Furthermore, theorists believe that the key determinants of a State's behavior towards international law is "not so much the nature and permeability of the domestic legal system as a whole, but rather the degree to which particular rules are or are not internalized into the domestic legal structure" (Koh, 1998, p. 675 ) and that States are "far more likely to comply with international law when they have accepted its legitimacy through some internal process." (Koh, 2006; Koh, 1998, p. 680)

Notwithstanding all these variants of the international obligation theory, the argument in some quarters still remain that MEAs are "relatively soft in their approach" since they usually "lack the force that treaties and conventions relating to human rights have." (UNESCO, 2011, p. 65) Moreover, unlike the much touted "hypothetical consent of individuals embodied in social contract theories", "expressed consent" has been argued by some scholars to be the "traditional basis of international law" and hence the source of obligation on States. The proposition has mostly been that "international institutions derive their powers from the explicit consent of the contracting states" and that such a "consent is not necessarily permanent" since the State might allocate these powers in a way that is "revocable." (Raustiala, 2003, p. 846) It has been similarly opined that having institutionalized international rules usually "instantiate and stabilize[s] the collective interests of states" though the flexibility in designing MEAs such as the CBD and the Framework Convention on Global Climate Change are useful designs for the "gradual evolution" which allows for the refining of State "interests." (Reus-Smit, 2004, p. 31)

\section{The Balanced Obligation and Compliance with International Law}

As is evident from the preceding sections, theories that seek to explain States' obligation to international law based on the concepts of interdependence and concrete consent of States have been either rejected or debunked by several scholars. (Reus-Smit, 2003; Posner, 2003; Teson, 1990) Indeed, questions on State obligation to international law "seems to many an important one, and distinguishable from the analogous question of the duty of obedience in domestic law" due mainly to the ideas of State sovereignty and independence. Thus making such a supposition of obligation "a higher authority" or "superior legal system" questionable. (Teson, 1990, p. 84) It is for this reason that this essay proposes another dimension to viewing the whole issue of international obligation - the idea of a balanced obligation. This balanced obligation emanates from the fact that even as responsible members of the international community and parties to several MEAs, most countries would intend to meet their international obligation even as they also tend to shoulder the domestic responsibility of improving the conditions of living of their citizens. As a result, seeking the right balance between the two becomes the most appropriate thing to do.

As a basis for this balanced obligation, we shall assume the following propositions as fundamentals:

1) It is the duty of every sovereign State to determine and charter a suitable path for its own internal development (legally, socially, economically, and politically). Unnecessary interference in the affairs of other States usually creates an imbalance and lack of trust in the international system and this leads to mutual suspicions - elements that usually form the basis for noncompliance to international law.

2) Sovereign States have the responsibility towards other sovereign States in ensuring that their actions and inactions do not pose undue negative threats to each other's territory in all dimensions (land, water, and space). If all States will be willing to abide by and make conscientious efforts to meet this assertion, there would be little to no interstate and border disputes around the globe.

3) Sovereign States must cooperate and coordinate to ensure that their citizens enjoy the most benefits in all aspects of their existence. Thus, when necessary, coordination and cooperation among sovereign States should be the key for achieving mutually desirable outcomes in the international system. By this coordination and cooperation, States must make all the necessary efforts to ensure there is adequate and prompt intentionally planned activities that would enhance the exchange of information and resources at all levels of governance and administration. Thus, the seemingly complexities of governance and related security issues must be carefully ironed out to reflect the interests of all parties for the mutual benefits of all. Coordination and cooperation thus 
imply the building of trust and understanding among all States at all levels for the maximization of mutual benefits.

4) The need to execute an international obligation should not necessarily negate the responsibility for meeting domestic responsibilities. The point must be noted that without the individual citizens there is no State, and without the State there is no international community, much more to speak of an international law. As such, the needs of the citizen must always be at the forefront of every perceivable international law. The idea of the inability to meet the demands of each citizen as they may wish does not invalidate this primary assertion (even as human rights does not permit that people are necessarily free to do whatever they like and when). Instead, the general will and aspirations of citizens must be the motivating factor for agreeing to international treaties. In other words, each State has a duty to ensure that the primary needs of their citizens are well taken into consideration when drafting any international agreement and that when the State fails to do this due to whatever reason(s), it does not necessarily imply noncompliance. Rather, there must be appropriate avenues for meeting both the international obligation so imposed and the domestic responsibility as required.

\section{Implementation of the CBD in Ghana and Implication for Theory}

To borrow the words of Steven Ferrey, “....nations often enter into treaties, or international agreements, that are driven primarily by their own internal environmental problems, and not necessarily because of the gravity of the international situation." (Ferrey, 2003, p. 565) Like any other international law or treaty, the CBD is a product of an international compromise; it is the outcome of a negotiated policy in the midst of questions of sovereignty and national interests. As such, no country (including Ghana) was obliged or required to sign or ratify the Convention. However, once a sovereign State willingly (or grudgingly) appends its signature, and takes the further step to ratify it, it becomes obligatory to live by the dictates and aspirations of the Convention. This consequently implies that even in the face of stern domestic opposition at a point in time, the country in question will still have to find a way to balance satisfying its domestic demands with meeting its international obligation. A failure leading to achieving one at the detriment of the other may come with some unpleasant and even at times hostile consequences. These consequences may take several forms ranging from electoral defeat to even political unrests at the domestic level, and retaliations, reputational loss, sanctions, and even international ostracisation, etc. at the global stage. This is what I would term as the consequences of an unbalanced obligation.

It is also important to note that a country's commitment to act in accordance with MEAs such as the CBD does not only serve as a guide for the prioritization of development policy, but can also provide meaningful opportunities and mechanisms for building Ecosystem Goods and Services. Thus, under such MEAs, many incentives are usually drawn from the donor community and private sector companies that offer monetary and non-monetary benefits for a country's participation in programmes that are committed to biodiversity conservation, carbon sequestration, and ecosystem restoration, etc. (Secretariat of the Convention on Biological Diversity [SCBD], 2010) Eventually, keeping the balance in terms of the national interest becomes paramount even as States would like to be associated with global norms, rules, and regulations which in turn also come with enviable returns and benefits. Thus, from the suspension of log exports in 1995 and the prohibition of chainsaw logging in 1998, to present days' fight against small-scale illegal mining and the prevention of illegal sand winning, etc., Ghana as a responsible yet pragmatic country, has tightened rules and regulations aimed at biodiversity conservation in lines with the CBD even as it seeks to make effective use of her natural resources. At the same time, policies are in place to ensure food security and emergency awareness, as well as improvement in productivity and rise in incomes through alternative livelihood projects. In effect, there is a balanced obligation at work - the country is cautiously optimistic about implementing international obligations that may harm domestic interests even as it is also not blind to the her international obligations and domestic responsibility.

Consequently, existing evidence gives an indication that though the Ghanaian State is as much interested in the welfare and wellbeing of its citizens, this legitimate interest has not prevented the State from introducing measures that will in one way or the other limit the excessive use of natural resources at the detriment of the existing generation and those unborn. More so, the State in her efforts to meet her international obligations as outlined in the CBD and other related MEAs has introduced policies that are aimed at mitigating the adverse effects that may result from limiting the extraction of certain natural resources for societal purposes. For instance to eradicate poaching and effectively regulate the illegal trading in wildlife and their parts means introducing alternative sources of livelihoods such as tree planting and forestry rangers and guards. A balance is thus seen to be struck between international obligation and national interest. Thus, contrary to the idea that legislations meant for giving effect to the implementation of MEAs in Ghana are "either inadequate to address the environmental problems" or "contradict the provisions of the international environmental convention from which it derives it 
source" (Okley, 2004, p. 57), the idea seems to be that of balancing the domestic interests of the State with that of international obligation - an approach that seems more realistic to meeting both domestic needs and international obligation.

The point must be reiterated that virtually all multilateral environmental agreements, treaties and conventions usually require national compliance and enforcement in order to achieve the desired goals as stipulated. Accordingly, the implementation of national policies, laws, and programmes becomes a necessity so as to ensure the effective execution of a globally established practice of environmental protection. It is at this juncture that the theories of international obligation come in to explain why States comply or are obliged to execute the tenets of agreements (and to which we argue that a case for a balanced obligation as a variant of the theory of international obligation seems quite suitable for explaining the how and why a State must comply with international law).

It must also be emphasised here that as a country that operates within the English common law system (mixed with customary law), Ghana, in terms of its assessment of the relations between domestic and international laws are concerned, maintains a similar view with that the English dualist conception. This thus implies that "Ghanaian courts will apply customary international law by virtue of incorporation" and as long as such laws are "consistent with an Act of Parliament." Moreover, for a treaty or convention to be binding on the country, it first has to be enacted into legislation. It has therefore been argued that for MEAs such as the CBD to have effect in the country, they would and must go through the same process since a failure to do that will only mean "the treaty will only be binding on Ghana in terms of its relationship with the international community." (Okley, 2004, p. 15)

While the judiciary of any State may in one way or the other, on the ground may disregard or overlook international law and make a decision that is contrary to international law by hiding behind the cloak of the independence of judiciary, the State in question may nevertheless, under normal circumstances be held responsible for any such breach on the international stage. (Hamid \& Sein, 2005) Thus, parties to international agreements and treaties in the international system are not necessarily independent from responsibility sovereignty does not equate irresponsibility (Kwarteng \& Botchway, 2019) and it is this that calls for balancing obligation. This balancing would be successful when the four fundamentals indicated earlier are carefully adhered to by States in their dealings in the international system.

Interestingly, some scholars are convinced that allowing the international legal system adequate space in the domestic affairs of States would "offer an effective response" that are capable of addressing new global challenges and "transnational threats" such as terrorism, cross-border pollution, refugee crisis, the proliferation weapons, etc (in effect, compliance with international law). It is in view of this that some argue that "the international legal system must be able to influence the domestic policies of states and harness national institutions in pursuit of global objectives." (Slaughter \& Burke-White, 2006, p. 328) This stems from the fact that it is believed that "the effectiveness of international law may... depend on its ability to shape political outcomes and institutional structures within states." (Slaughter \& Burke-White, 2006, p. 339) As good as these assertions by Slaugther and Burke-White may sound; one must note that we are dealing with Sovereign States entities that form the basis for the very practice of international law. The European Union model been romanticized and advocated by Slaugther and Burke-White (2006) is not as ideal as time has proven (consider Brexit, the recent migration crisis, and anti-EU slogans). A better option will be to encourage States to balance their obligations.

\section{References}

Botchway, T. P. (2018). International Law, Sovereignty and the Responsibility to Protect: An Overview. Journal of Politics and Law, 11(4), 40-50. https://doi.org/10.5539/jpl.v11n4p40

Botchway, T. P., \& Kwarteng, A. H. (2018). Developing International Law in Challenging Times. Journal of Politics and Law, 11(3), 53-63. https://doi.org/10.5539/jpl.v11n3p53

Carty, A. (1991). Critical International Law: Recent Trends in the Theory of International Law. European Journal of International Law, 1-27. https://doi.org/10.1093/ejil/2.1.66

Chayes, A., \& Chayes, A. H. (1986). Testing and Development of Exotic Systems under the ABM Treaty: The Great Reinterpretation Caper. Harvard Law Review, 99(1956), 1956-1971. https://doi.org/10.2307/1341215

Crossen, T. E. (2003). Multilateral Environmental Agreements and the Compliance Continuum. Retrieved September 3, 2018, from https://core.ac.uk/display/76622369

D'Amato, A. (2009). The Coerciveness of International Law. German Yearbook of International Law, 52, 437-460. 
D'Amato, A. (2010). A Few Steps Toward an Explanatory Theory of International Law. Northwestern University School of Law. Chicago: Northwestern University School of Law Scholarly Commons. Retrieved from $\mathrm{http} / / /$ scholarlycommons.law.northwestern.edu/facultyworkingpapers/90

Dominicé, C. (1999). The International Responsibility of States for Breach of Multilateral Obligations. European Journal of International Law, 10(2), 353-363. https://doi.org/10.1093/ejil/10.2.353

Ferrey, S. (2003). Environmental Law: Examples \& Explanations (2nd ed.). Beijing: Citic Publishing House.

Guzman, A. T. (2002, December). A Compliance-Based Theory of International Law. California Law Review, 90(6), 1823-1888. https://doi.org/10.2307/3481436

Hamid, A. G., \& Sein, K. M. (2005). Judicial Application of International Law in Malaysia: An Analysis. Asia-Pacific Yearbook of International Humanitarian Law, 1(196), 195-214.

Hardin, G. (1968). The Tragedy of the Commons. Science, 162(3859), 1234-1248. https://doi.org/10.1126/science.162.3859.1243

He, Q. (2016). Chronology of Practice: Chinese Practice in Private International Law in 2015. Chinese Journal of International Law, 15, 859-901. https://doi.org/10.1093/chinesejil/jmw042

International Commission on Intervention and State Sovereignty (ICISS). (2001). The Responsibility to Protect: Report of the International Commission on Intervention and State Sovereignty. Ottawa: International Development Research Centre.

Koh, H. H. (1997). Why Do Nations Obey International Law? The Yale Law Journal (Faculty Scholarship Series. Paper 2101), 2598-2659. Retrieved from http://digitalcommons.law.yale.edu/fss_papers

Koh, H. H. (1998). 1998 Frankel Lecture: Bringing International Law Home. Houston Law Review (Faculty Scholarship Series. Paper 2102), 623-681. Retrieved from $\mathrm{http} / / /$ digitalcommons.law.yale.edu/fss_papers/2102

Koh, H. H. (2006). Why Transnational Law Matters. Penn State International Law Review, 24(4), 745-753. Retrieved from elibrary.law.psu.edu/psilr/vol24/iss $4 / 4$

Kwarteng, A. H., \& Botchway, T. P. (2018). The North and South Divide in the Practice and Application of International Law: A Humanitarian and Human Right Law Perspective. Journal of Politics and Law, 11(1), 79-87. https://doi.org/10.5539/jpl.v11n1p79

Kwarteng, A. H., \& Botchway, T. P. (2019). State Responsibility and the Question of Expropriation: A Preliminary to the "Land Expropriation without Compensation" Policy in South Africa. Journal of Politics and Law, 12(1), 98-107. https://doi.org/10.5539/jpl.v12n1p98

Mitchell, R. B. (2007). Compliance Theory: Compliance, Effectiveness, and Behavior Change in International Environmental Law. In J. Brunee, D. Bodansky, \& E. Hey (Eds.), Oxford Handbook of International Environmental Law (pp. 893-921). Oxford: Oxford University Press. https://doi.org/10.1093/oxfordhb/9780199552153.013.0039

Okley, B. L. (2004). Legislation and Implementation of International Environmental Law by African Countries: a Case Study of Ghana. University of Georgia, School of Law. Athens: Student Works and Organizations at Digital Commons@ Georgia Law. Retrieved from http://digitalcommons.law.uga.edu/stu_llm/38

Pemmaraju, S. R. (2016). The South China Sea Arbitration (The Philippines v. China): Assessment of the Award on Jurisdiction and Admissibility. Chinese Journal of International Law, 15(2), 265-307. https://doi.org/10.1093/chinesejil/jmw019

Posner, E. A. (2003). Do States Have a Moral Obligation to Obey International Law? Stanford Law Review, 1901-1920.

Posner, E. A., \& Goldsmith, J. L. (1999). A Theory of Customary International Law. University of Chicago Law Review, 66, 1113-1178. https://doi.org/10.2307/1600364

Raustiala, K. (2003). Rethinking the Sovereignty Debate in International Economic Law. Journal of International Economic Law, 6(4), 841-878. https://doi.org/10.1093/jiel/6.4.841

Reus-Smit, C. (2003). Politics and International Legal Obligation. European Journal of International Relations, 9(4), 591-625. https://doi.org/10.1177/135406610394003

Reus-Smit, C. (2004). The Politics of International Law. In C. Reus-Smit (Eds.), The Politics of International Law (pp. 14-44). Cambridge: Cambridge University Press. https://doi.org/10.1017/CBO9780511491641 
Secretariat of the Convention on Biological Diversity. (2010). Ecosystem Goods and Services in Development Planning: A Good Practice Guide. Montreal: Secretariat of the Convention on Biological Diversity.

Slaughter, A.-M., \& Burke-White, W. (2006). The Future of International Law Is Domestic (or, the European Way of Law). Harvard International Law Journal, 47(2), 327-352.

Teson, F. R. (1990). International Obligation and the Theory of Hypothetical Consent. Yale Journal of International Law, 15(1), 84-120. Retrieved from http://digitalcommons.law.yale.edu/yjil/vol15/iss1/3

UNESCO. (2011). Ethics and Biodiversity. Bangkok: UNESCO.

\section{Notes}

Note 1. This essay is an expanded version of a section in the Author's $\mathrm{PhD}$ thesis. The ideas presented here forms the basis for building a case for why and how States can effectively comply with international law and equally achieve domestic targets on issues of sustainable development which is key to the Convention on Biological Diversity.

Note 2. This is a Latin term in agreements which stipulate that the terms of the agreement must be kept by all signatories.

\section{Copyrights}

Copyright for this article is retained by the author(s), with first publication rights granted to the journal.

This is an open-access article distributed under the terms and conditions of the Creative Commons Attribution license (http://creativecommons.org/licenses/by/4.0/). 